\title{
ESTABLISHING STEINER CEPHALOMETRIC NORMS FOR EGYPTIAN CHILDREN - A RETROSPECTIVE STUDY
}

\author{
Ahmed Maher Fouda*
}

\begin{abstract}
Objectives: The facial characteristics of Egyptian children were examined using Steiner analysis.

Material and Methods: Sixty children were included in the study (40 girls and 20 boys). The selection criteria were: all in mixed dentition stage (mean age: $9.27 \pm 1.57$ years), acceptable profile, absence of craniofacial deformities, normal overjet and overbite and no crossbite. This retrospective study was chosen to avoid unnecessary radiation exposure. All children had previously undergone cephalometric analysis for follow up and supervision at 6 month intervals. Sixteen cephalometric measurements according to Steiner analysis were recorded and analyzed statistically.

Results: The most pronounced changes between girls and boys were Sn-GoGn which was steeper in girls and SL (the length of the anterior cranial base) which was larger in boys than girls.

Conclusion: No significant difference was found between boys and girls except for the above measurements, the measurements values of this research can be used as cephalometric standards for Egyptian children in the mixed dentition period.
\end{abstract}

\section{INTRODUCTION}

Every orthodontist should be familiar with human craniofacial growth and development ${ }^{1}$. Variability of craniofacial growth is a concept ${ }^{2}$. The obtained values of measurements are compared with the standard values, in order to classify and diagnose a malocclusion of the teeth. Measurements that considered normal for one group cannot be applied to another racial group according to cephalometric studies on different ethnic groups. ${ }^{3}$ lateral cephalometric film is used very frequently for the diagnosis of craniofacial and dento-facial disharmonies. ${ }^{4}$ Norms should be available for children at the age which entails correction of dental and skeletal malocclusion. ${ }^{5}$ As the numbers of Egyptian children seeking orthodontic treatment has been increased, normality of the face for children is necessary to be comprised..$^{6,8}$ Till date fewer studies has been conducted on Egyptian children in order to find out various cephalometric measurements of dental and skeletal structures by means of Steiner

\footnotetext{
* Assistant Professor of Orthodontics, Faculty of Dentistry, Mansoura University
} 
analysis. ${ }^{5,6,7,9,10}$ Steiner analysis used to diagnose hard and soft tissues using lateral cephalometric radiographs. ${ }^{11,12}$ Under the above mentioned background, this study was conducted for Egyptian children in the mixed dentition analysis in order to identify various hard tissue cephalometric values with Steiner analysis means for clinical application of the findings. Clarification of racial difference (if present or not) of the cephalometric norms among different population was another aim.

\section{MATERIAL AND METHODS}

The study sample was obtained from the records of the author's private practice. The data of the patients were conditional and their data were represented in a manner that not reflect identification of any patient. The sample consisted of sixty Egyptian children (20 boys and 40 girls with mean age of $9.27 \pm 1.57$ years) with good quality cephalograms. The children were in the age of 6-12 years. Additional inclusion criteria were normal acceptable and pleasing profile. Absence of craniofacial deformities, normal overjet and overbite and no crossbite. All set of complement teeth was present for that age. When this study was embraced, a retrospective study was chosen for fear of unnecessary radiation exposure to the children. All the children had previously undergone cephalometric analysis for follow up and supervision at 6 months intervals. Most of these children had shown up in the clinic seeking conservative orthodontic treatment of their teeth and inquiring about ugly duckling stage and were supervised in an effort to discover any abnormalities of teeth. All cephalograms were digitally traced**. A sample of 10 cephalograms were randomly picked and retraced for inter-examiner consistency. There was no significant difference between manual and digital tracing of the cephalograms ${ }^{13}$. Ten angular and six linear measurements according to steiner analysis were recorded and analyzed (figure 1).

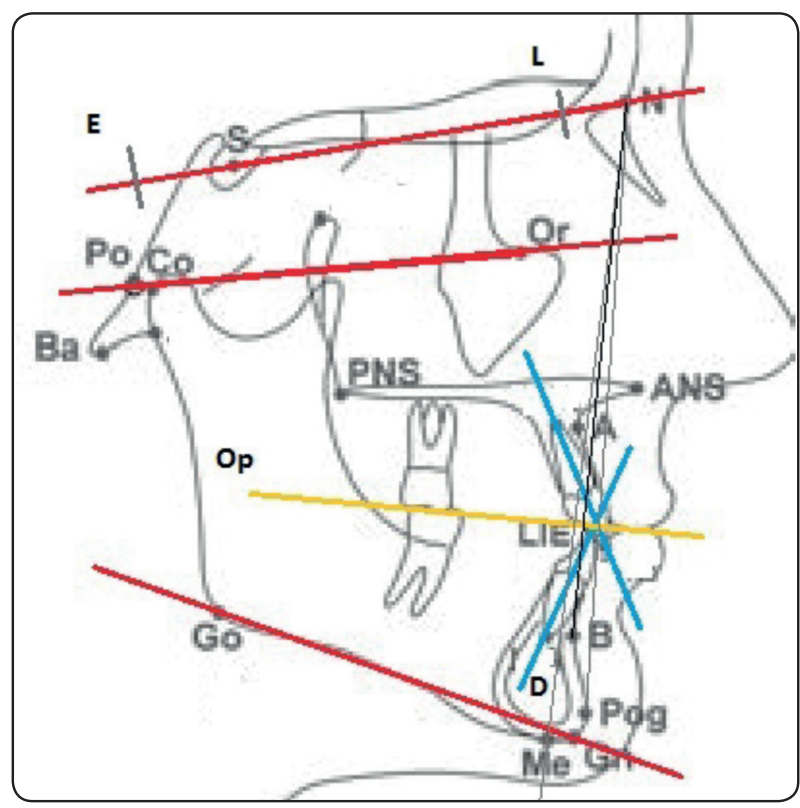

Fig (1): Steiner analysis reference points. 1-SNA; 2-SNB; 3-ANB; 4-SND; 5- Interincisal angle; 6- SN-Op; 7SN-GoGn; 8- Max 1- NA (angle); 9- Max 1-NA (mm); 10- Mand 1-NB (angle); 11-Mand 1-NB (mm); 12pog - NB; 13-SL (mm); 14- SE (mm). 15- Max 1-SN (angle); 16- Holdway ratio.

\section{Statistical analysis}

IBM SPSS software package version 20.0. (Armonk, NY: IBM Corp) ${ }^{(2)}$ was used to analyze the desired data. The normality of distribution was verified by Kolmogorov-Smirnov test. Quantitative data were described using range (minimum and maximum), mean, standard deviation and median. The 5\% level of the obtained results was qualified to be Significance.

\section{The used tests were:}

\section{1 - Student t-test}

To compare between two studied groups. For normally distributed quantitative variables,

\section{2 - Mann Whitney test}

To compare between two studied groups. For abnormally distributed quantitative variables,

\footnotetext{
* Assistant Professor of Orthodontics, Faculty of Dentistry, Mansoura University
} 


\section{RESULTS}

TABLE (1): Comparison between the two studied groups according to age

\begin{tabular}{|c|c|c|c|c|c|}
\hline & $\begin{array}{c}\text { Total } \\
(\mathbf{n = 6 0})\end{array}$ & $\begin{array}{c}\text { Boys } \\
(\mathbf{n = 2 0})\end{array}$ & $\begin{array}{c}\text { Girls } \\
(\mathbf{n = 4 0 )}\end{array}$ & $\mathbf{t}$ & \\
\hline Age (years) & & & & \\
Min. - Max. & $5.92-12.0$ & $6.0-11.75$ & $5.92-12.0$ & \\
Mean \pm SD. & $9.27 \pm 1.57$ & $9.39 \pm 1.60$ & $9.21 \pm 1.57$ & 0.418 & 0.677 \\
Median & 9.0 & 9.38 & 9.0 & \\
\hline
\end{tabular}

$t$ : Student t-test

p: p value for comparing between the two groups

TABLE (2): Comparison between the two studied groups according to different parameters

\begin{tabular}{|c|c|c|c|c|}
\hline & $\begin{array}{c}\text { Total } \\
(\mathbf{n}=60)\end{array}$ & $\begin{array}{c}\text { Boys } \\
(\mathbf{n}=\mathbf{2 0})\end{array}$ & $\begin{array}{c}\text { Girls } \\
(\mathrm{n}=\mathbf{4 0})\end{array}$ & $\mathbf{p}$ \\
\hline \multicolumn{5}{|l|}{ SNA } \\
\hline Min. - Max. & $73.0-88.0$ & $73.0-88.0$ & $75.0-87.0$ & \\
\hline Mean \pm SD & $80.80 \pm 3.27$ & $81.20 \pm 4.26$ & $80.60 \pm 2.68$ & 0.570 \\
\hline Median & 80.50 & 81.0 & 80.0 & \\
\hline \multicolumn{5}{|l|}{ SNB } \\
\hline Min. - Max. & $70.0-85.0$ & $71.0-85.0$ & $70.0-82.0$ & \\
\hline Mean \pm SD & $76.83 \pm 3.54$ & $77.75 \pm 4.24$ & $76.38 \pm 3.09$ & 0.158 \\
\hline Median & 77.50 & 78.0 & 77.0 & \\
\hline \multicolumn{5}{|l|}{ ANB } \\
\hline Min.-Max. & $-2.0-9.0$ & $-2.0-9.0$ & $-1.0-7.0$ & \\
\hline Mean \pm SD & $3.93 \pm 2.47$ & $3.50 \pm 3.05$ & $4.15 \pm 2.13$ & 0.282 \\
\hline Median & 4.0 & 3.50 & 4.0 & \\
\hline \multicolumn{5}{|l|}{ SND } \\
\hline Min. - Max. & $67.0-81.0$ & $68.0-81.0$ & $67.0-79.0$ & \\
\hline Mean \pm SD & $73.40 \pm 3.36$ & $74.10 \pm 4.12$ & $73.05 \pm 2.91$ & 0.257 \\
\hline Median & 74.0 & 74.0 & 73.50 & \\
\hline \multicolumn{5}{|l|}{ Interincisal angle } \\
\hline Min. - Max. & $105.0-156.0$ & $112.0-156.0$ & $105.0-152.0$ & \\
\hline Mean \pm SD & $127.0 \pm 11.42$ & $130.6 \pm 12.28$ & $125.2 \pm 10.68$ & 0.086 \\
\hline Median & 127.5 & 128.5 & 125.0 & \\
\hline
\end{tabular}

p: $p$ value for comparing between the two groups

*: Statistically significant at $p \leq 0.05$ 
TABLE (3): Comparison between the two studied groups according to different parameters

\begin{tabular}{|c|c|c|c|c|}
\hline & $\begin{array}{c}\text { Total } \\
(n=60)\end{array}$ & $\begin{array}{c}\text { Boys } \\
(n=20)\end{array}$ & $\begin{array}{c}\text { Girls } \\
(n=40)\end{array}$ & $\mathbf{p}$ \\
\hline \multicolumn{5}{|l|}{ SN-OcP } \\
\hline Min. - Max. & $12.0-28.0$ & $12.0-28.0$ & $12.0-27.0$ & \multirow{3}{*}{0.172} \\
\hline Mean \pm SD & $20.82 \pm 3.71$ & $19.75 \pm 4.61$ & $21.35 \pm 3.10$ & \\
\hline Median & 21.0 & 19.50 & 21.50 & \\
\hline \multicolumn{5}{|l|}{ SN-GoGn } \\
\hline Min. - Max. & $24.0-49.0$ & $24.0-44.0$ & $27.0-49.0$ & \multirow{3}{*}{0.008} \\
\hline Mean \pm SD & $35.60 \pm 5.22$ & $33.10 \pm 4.63$ & $36.85 \pm 5.09$ & \\
\hline Median & 35.0 & 33.0 & 38.0 & \\
\hline \multicolumn{5}{|l|}{ Max1-SN } \\
\hline Min. - Max. & $1.0-39.0$ & $4.0-39.0$ & $1.0-38.0$ & \multirow{3}{*}{0.500} \\
\hline Mean \pm SD & $20.85 \pm 7.23$ & $19.95 \pm 7.86$ & $21.30 \pm 6.96$ & \\
\hline Median & 21.0 & 20.0 & 22.0 & \\
\hline \multicolumn{5}{|l|}{ Max1-NA } \\
\hline Min. - Max. & $9.0-124.0$ & $80.0-124.0$ & $9.0-122.0$ & \multirow{3}{*}{0.677} \\
\hline Mean \pm SD & $100.3 \pm 14.76$ & $100.9 \pm 9.08$ & $100.0 \pm 17.01$ & \\
\hline Median & 101.0 & 100.0 & 102.0 & \\
\hline \multicolumn{5}{|l|}{ Mand1-NB } \\
\hline Min. - Max. & $3.0-45.0$ & $3.0-45.0$ & $9.0-42.0$ & \multirow{3}{*}{0.164} \\
\hline Mean \pm SD & $28.20 \pm 7.84$ & $26.20 \pm 9.54$ & $29.20 \pm 6.75$ & \\
\hline Median & 29.0 & 28.0 & 29.0 & \\
\hline
\end{tabular}

p: $p$ value for comparing between the two groups *: Statistically significant at $p \leq 0.05$

TABLE (4): Comparison between the two studied groups according to different parameters

\begin{tabular}{|c|c|c|c|c|}
\hline & $\begin{array}{c}\text { Total } \\
(n=60)\end{array}$ & $\begin{array}{c}\text { Boys } \\
(\mathbf{n}=\mathbf{2 0})\end{array}$ & $\begin{array}{c}\text { Girls } \\
(n=40)\end{array}$ & $\mathbf{p}$ \\
\hline \multicolumn{5}{|l|}{ 1u-NA (mm) } \\
\hline Min. - Max. & $-1.0-8.0$ & $0.0-8.0$ & $-1.0-8.0$ & \\
\hline Mean \pm SD & $4.08 \pm 1.99$ & $4.0 \pm 2.18$ & $4.13 \pm 1.92$ & 0.848 \\
\hline Median & 4.0 & 4.0 & 4.0 & \\
\hline \multicolumn{5}{|l|}{ 1L-NB (mm) } \\
\hline Min. - Max. & $1.0-10.0$ & $1.0-8.0$ & $2.0-10.0$ & \\
\hline Mean \pm SD & $5.22 \pm 1.83$ & $4.95 \pm 1.88$ & $5.35 \pm 1.82$ & 0.599 \\
\hline Median & 5.0 & 5.0 & 5.0 & \\
\hline \multicolumn{5}{|l|}{ Pog-NB } \\
\hline Min. - Max. & $-3.0-3.0$ & $-2.0-3.0$ & $-3.0-3.0$ & \\
\hline Mean \pm SD & $-0.17 \pm 1.39$ & $0.05 \pm 1.32$ & $-0.28 \pm 1.43$ & 0.384 \\
\hline Median & 0.0 & 0.0 & 0.0 & \\
\hline \multicolumn{5}{|l|}{ Holdway Ratio } \\
\hline Min. - Max. & $0.0-11.0$ & $1.0-10.0$ & $0.0-11.0$ & \\
\hline Mean \pm SD & $5.30 \pm 2.68$ & $4.95 \pm 2.50$ & $5.48 \pm 2.77$ & 0.426 \\
\hline Median & 5.0 & 5.0 & 5.50 & \\
\hline
\end{tabular}


TABLE (5): Comparison between the two studied groups according to different parameters

\begin{tabular}{|l|c|c|c|c|}
\hline & $\begin{array}{c}\text { Total } \\
(\mathbf{n = 6 0})\end{array}$ & $\begin{array}{c}\text { Boys } \\
(\mathbf{n = 2 0})\end{array}$ & $\begin{array}{c}\text { Girls } \\
(\mathbf{n = 4 0 )}\end{array}$ & $\mathbf{p}$ \\
\hline SL $(\mathbf{m m})$ & & & & \\
Min. - Max. & $22.0-58.0$ & $26.0-58.0$ & $22.0-54.0$ & $0.010^{*}$ \\
Mean \pm SD. & $39.20 \pm 7.91$ & $42.85 \pm 8.0$ & $37.38 \pm 7.30$ & \\
Median & 39.0 & 43.0 & 38.0 & \\
\hline SE $(\mathbf{m m})$ & & & $13.0-24.0$ & 0.913 \\
Min. - Max. & $13.0-24.0$ & $13.0-23.0$ & $17.83 \pm 2.54$ & \\
Mean \pm SD. & $17.85 \pm 2.47$ & $17.90 \pm 2.38$ & 17.0 & \\
Median & 18.0 & 18.0 &
\end{tabular}

$p: p$ value for comparing between the two groups

\section{DISCUSSION}

This Study was carried out to determine cephalometric norms for sixty Egyptian children (40 girls and 20 boys) in the mixed dentition period from age 6 to 12 years. The only variables that differed between girls and boys were the angle Sn-GoGn and the linear distance SL (table: 2, 3, $4,5)$. The angle Sn-GoGn was larger in girls than that in boys indicating larger lower face height for the girls. The length of anterior cranial base of the boys was lesser than that for the girls. The mean values for the comparison of the skeletal angular measurements of the boys and girls of the present study were in accordance to those of Afifi except the interincisal angle which was more obtuse in the present study declaring more upright position. ${ }^{9}$ The inclination of the upper incisors to NA in the present study was lower $\left(21^{\circ}\right)$ comparing to other results indicating less labial inclination of the upper incisors of the present study. ${ }^{9,10}$ Also the inclination of the mandibular incisors to NB was less $\left(28^{\circ}\right)$ than the value of other studies, but in accordance to the value of Soliman`s study $\left(29^{\circ}\right) .8,9,10$ The apical base relationship of the present study was the same as those dealing with Steiner analysis of Egyptian
$*$ : Statistically significant at $p \leq 0.05$ children ${ }^{8,9,10,14}$ The present study agrees with the study Bishara, Drevensek, Eldiassy and Meka et al on Caucasian, Slovenian, Libyan and Indian children regarding the antero-posterior apical base relationship and incisor inclination. ${ }^{15-18}$ From the results of the present studies, it was clear that there was no racial differences of the cephlometric norms among different population..$^{19,20}$

\section{CONCLUSION}

1. The present study derived cephalometric norms of Steiner analysis for diagnosis of dental and skeletal problems for Egyptian children of 6-12 years of age.

2. None significant differences were found skeletally and dentally between girls and boys in the present study sample except SN-GoGn and SL.

3. The apical base relationship of the Egyptian children indicated backward position of the lower jaw to the cranium and to the upper jaw.

4. There was no racial difference regarding Steiner cephalometric norms of the Egyptian children in the mixed dentition age (6-12 years). 


\section{REFERENCES}

1- Moyers RE. Analysis of craniofacial skeleton cephalometric. Handbook of orthodontics for the students and the general practitioner. Chicago: 1988: 247.

2- Rathore A S, Dhar V, Diwanji A. Cephalometric norms for Mewari children using steiner analysis. Int J Clin Pediatr Dent. 2012;5(3):173-177.

3- Drummond RA. A determination of cephalometric norms for the Negro race. Am J Orthod. 1968;54(9):670-682.

4- McNamara JA. A method of cephalometric evaluation. . Am J Orthod. 1984;86(6):449-469.

5- El-Hadary ME, Abou-ElAzm SF. Malocclusion in male young adults. Tanta Med J. 1977;5:337-346.

6- El-Mangoury NH and Mostafa YA. Epidemiologic panorama of dental occlusion. Angl Orthod. 1987;60(3):207-214.

7- Sahitya M, Shashidhar EP, Chidanandeswara GC, Shetty SK, Kumar YM. Establishing cephalometric norms using sagittal and vertical occlusal cephalometric analysis of Pancherz for dakshina kannada children. J of Int Oral Health. 2015;7(7):48-52.

8- Abou-Al amayem SM. Cephalometric norms for egyption children aged nine to twelve years. Master thesis. Faculty of dentistry, Alexandria, Egypt 1982.

9- Afifi HA. Application of Steiner's analysis on a group of egyptian children. Master thesis. Faculty of dentistry, Cairo, Egypt 1982.

10- Soliman S. A comparison between the cephalometric analysis as carried out by downs, steiner and wits in measuring the degree of antero-posterior jaws relationship. Master thesis. Faculty of dentistry, Cairo, Egypt 1982.

11- Fouda MA. SIF, a revisted method of apical jaw relationship. AL-Azhar Dent J. 1987;2(6):661-671.

12- Steiner CC. Cephalometric for you and me. Am J Orthod. 1953;39(10):729-755.

13- Steiner CC. Cephalometric as a clinical book. Vistas in Orthodontics. 1962:131-161.

14- El-Sayed AA, Fouda MA, Abdallah EM. Lateral cephalometric x-ray for preschool children (3-6 years) in Alexandria. Egypt Ortod J. 1991;5(1):25-35.

15- Bishara SE. Longitudnal cephalometric standards from 5 years of age to adulthood. Am J Orthod. 1981; 79(1):35-45.

16- Drevensek M, Vidmar G. Cephalometric standards for Slovenians in the mixed dentition period. Eur J Orthod. 2006;28:51-57.

17- Eldaissy AM. Cephalometric norms of Libyan children in mixed dentition phase. Cairo Dent J. 2008;24(3):531-535.

18- Meka $\mathrm{M}$ et al. Establishing lateral cephalometric norms for nalgonda children with mixed dentition. J Orthod Res .2015;3(2):134-137.

19- Gayati G, Harsanti A, Zenab Y, Rahmat I. Steiner cephalometric analysis discrepancies between conventional and digital methods using cephninja application software. Padjadjaran J Dent. 2016;28(3):148-152.

20- Hamdan AM, Rock WP. Cephalometric norms in an Arabic population. J Orthod $2001 ; 28(4): 297-300$. 